\title{
Corrosion Evaluation of Pipeline Steel API 5L X52 in partially deaerated Produced Water with High Chloride Content
}

\author{
Natalya V. Likhanova ${ }^{1}$, Noel Nava $^{1}$, O. Olivares-Xometl ${ }^{2, *}$, M.A. Domínguez-Aguilar ${ }^{1}$, P Arellanes- \\ Lozada ${ }^{2}$, Irina V. Lijanova ${ }^{3}$, Janette Arriola-Morales ${ }^{2}$, Luis Lartundo-Rojas ${ }^{4}$. \\ ${ }^{1}$ Instituto Mexicano del Petróleo, Eje Central Lázaro Cárdenas No. 152, Col. San Bartolo \\ Atepehuacan, México D.F. 07730, México. \\ ${ }^{2}$ Benemérita Universidad Autónoma de Puebla, Facultad de Ingeniería Química, Av. San Claudio, \\ Ciudad Universitaria. Col. San Manuel, Puebla, Pue. 72570, México. \\ ${ }^{3}$ Instituto Politécnico Nacional, CIITEC, Cerrada Cecati S/N, Colonia Santa Catarina, Azcapotzalco, \\ México D.F. 02250, México. \\ ${ }^{4}$ Instituto Politécnico Nacional, Centro de Nanociencias y Micro y Nanotecnologías, UPALM, \\ Zacatenco, México D.F. CP. 07738, México \\ *E-mail: oxoctavio@yahoo.com.mx
}

doi: $10.20964 / 2018.08 .13$

Received: 17 March 2018 / Accepted: 14 May 2018 / Published: 5 July 2018

\begin{abstract}
The corrosion mechanism of pipeline steel X52 exposed to produced water is proposed based on identified chemical species and scale after 270 days. Polarization curve profiles suggested that steel corrosion products are formed and removed periodically. X-ray diffraction, Mössbauer and Ultravioletvisible spectroscopies identified akaganeite/lepidocrocite $\left(\mathrm{Fe}^{3+} \mathrm{O}(\mathrm{OH})\right)$ along with goethite $(\alpha-\mathrm{FeOOH})$ and magnetite $\left(\mathrm{Fe}_{3} \mathrm{O}_{4}\right)$ as a result of iron oxidation in water to conform an external layer. XPS detected the presence of $\mathrm{FeCl}_{2}$ and $\mathrm{Fe}_{2}\left(\mathrm{SO}_{4}\right)_{3}$ in the internal layer derived from previous adsorption on the surface. SEM indicated the presence of general and localized corrosion under corrosion products.
\end{abstract}

Keywords: Pipeline steel; Corrosion behavior; Produced water; Surface analysis; Electrochemical techniques.

\section{$\underline{\text { FULL TEXT }}$}

(C) 2018 The Authors. Published by ESG (www.electrochemsci.org). This article is an open access article distributed under the terms and conditions of the Creative Commons Attribution license (http://creativecommons.org/licenses/by/4.0/). 